Araştırma Makalesi

\title{
16 Nisan 2017 Referandumunun Gazete Manşetlerindeki Sunumu: Hürriyet, Sabah, Sözcü ve Posta Örneğiyle
}

\author{
Meryem Altıntaş (Arş. Gör.) \\ Dicle Üniversitesi İletişim Fakültesi \\ meryem_tolan@hotmail.com \\ Orcid: 0000-0003-1896-3393
}

Başvuru Tarihi: 31.08.2018

Yayına Kabul Tarihi: 07.12.2018

Yayınlanma Tarihi: 21.01.2019

\section{Öz}

Toplumda referandumun siyasi bir tercih olarak algılanması nedeniyle siyasi partiler, halkı aydınlatmak amacıyla yürütülen siyasal kampanyaların yanında halkın 'evet' ya da 'hayır' yönündeki oyunu kullanmada yapacakları tercihleri etkileyebilmek adına birtakım çalışmalar yapmaktadırlar. Siyasi partilerin referandum oylamasında etkili olma bakımından yaptıkları siyasal iletişim faaliyetlerini halka duyurmada en önemli araç basındır. Çalışmada basının referandum sürecinde siyasal partilerin yapmış oldukları siyasal iletişim faaliyetlerini nasıl yansıttı̆̆ını ortaya koymak amaçlanmıştır. Bu amaç doğrultusunda Hürriyet, Sabah, Sözcü ve Posta gazetelerinin 15 Nisan 2017, 16 Nisan 2017 ve 17 Nisan 2017 tarihleri arasinda referandumla ilgili birinci sayfalarından vermiş oldukları toplamda 12 manşet haber Van Dijk'in söylem analizi yöntemi çerçevesinde değerlendirilerek analiz edilmiştir. Araştırma kapsamında incelenen gazetelerin referandumla ilgili bazı haberlerini nesnellikten uzak editöryal bir yanlılıkla yansıttığı sonucuna ulaşılmıștır.

Anahtar Kelimeler: Referandum, Siyasal İletişim, Haber, Söylem Analizi. 


\title{
Presentation of April 16, 2017 Referendum On Newspaper Headlines Hürriyet, Sabah, Sözcü and Posta Example
}

\author{
Meryem Altıntaş (Res. Asst.) \\ Dicle University Faculty of Communication \\ meryem_tolan@hotmail.com \\ Orcid: 0000-0003-1896-3393
}

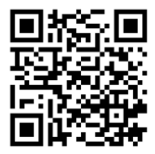

Date Received: 31.08.2018

Date Accepted: 07.12.2018

Date Published: 21.01.2019

\section{Abstract}

Since referendum is perceived as a political choice in society, along with the political campaigns ran on the purpose of enlightening the community, political parties are also carrying out certain works in order to affect the choices of the people will make in voting 'yes' or 'no' in the referendum. The most important instrument to announce the political communication activities with regards to being influent in referendum votes to public is media. It is aimed in the study to reveal how the media reflects the political communication activities that political parties carry out during the referendum period. In accordance with this purpose, 12 news headlines in total that were published by Hürriyet, Sabah, Sözcü and Posta newspapers on their front pages on the dates of April 15, 2017, April 16, 2017 and April 17, 2017 with regards to referendum were evaluated and analyzed within the framework of Van Dijk's discourse analysis method. It is concluded within the scope of the research that the newspapers analyzed reflect some of the news regarding referendum far from objectivity with an editorial bias.

Keywords: Referendum, Political Communication, News, Discourse Analysis. 


\title{
Giriş
}

Siyasi partiler, seçim dönemlerinde yürüttükleri siyasal kampanyalarla halkın oy tercihlerini etkileyebilmek amacıyla birtakım iletişim çalışmaları yürütmektedirler. Siyasal iletişim faaliyetleri olarak adlandırılan bu çalışmalarla ilgili bilgiler medya aracılı̆̆ı ile geniş kitlelere ulaştırılmaktadır.

Kalender $(2005,80)$, iletişim faktörlerinin çok iyi kullanılmasının siyasi partilere olumlu katkılar sağlayacağını şöyle açıklamaktadır:

\begin{abstract}
"Bir parti veya bir lider ne kadar bașarılı çalıșmalar yaparsa yapsın, ne kadar tutarlı ve gerçekçi vaadler verirse versin bunları seçmen kitlesine duyurmadıkça, bașarılı bir imaj oluşturmadıkça, ikna edemedikçe ayakta durması mümkün olmamaktadır. Hatta propaganda ve iletişim faktörlerinin çok iyi kullanılmasıyla kısa vadede, başarısız bir parti ve adayın başarılı gibi gösterilmesi bile gerçekleştirilebilir".
\end{abstract}

Siyasal iletişime yönelik Advan (2016, 324), "siyasi partilerin, bu partilerin liderlerinin, siyaset ile ilgili olan kişilerin özellikle seçim kampanyaları döneminde kamuoyuna ulaşabilmek ve onların oy verme davranışlarını istenilen yönde değiștirebilmek amacıyla gerçekleştirdikleri siyasal faaliyetler" tanımlamasını yapmıştır. Advan'ın bu tanımlamasında özellikle 'seçim kampanyaları' dönemine vurgu yapmasının nedenini ise siyasal iletişimin salt seçim kampanyaları döneminde yapılan çalışmalar olarak düşünülmesinden kaynaklı olduğunu belirterek açıklamıştır. Siyasal iletişim faaliyetleri sadece seçim dönemlerinde değil siyasetin olduğu her an yapılması gereken faaliyetlerdir. Özsoy $(2009,31)$ : "Siyasal iletişim, bir yönüyle siyasette denetim ve şeffaflığı sağlarken, diğer yönüyle de siyasetçilerin seçmenleri demokratik ikna metotlarıyla etkilemelerine yardımcı olan bir araç görevi de görmektedir".

"Referandum aracılığıyla halkın özgür iradesi doğrudan doğruya siyasal yaşama yansımaktadır. $\mathrm{Bu}$ sebeple referandum, yarı doğrudan demokrasinin güzel bir örneğini olușturmaktadır" (Göker ve Doğan, 2011, 47). Referandum sürecinde halkın aydınlatılması için yapılan siyasal kampanyalar, basın aracılığıyla daha geniş kitlelere ulaşmaktadır. Ülkemizde 16 Nisan 2017 tarihinde gerçekleştirilen referandumda seçmenin yüzde 51.41'lik 'evet' oyuyla anayasa değişikliği kabul edilmiştir. Siyasi partiler, diğer seçim dönemlerinde olduğu gibi 16 Nisan 2017 referandumu sürecinde de yoğun siyasal kampanyalar yürütmüşlerdir ve yapmış oldukları bu faaliyetleri basın aracılılığıyla halka duyurmuşlardır.

Çalışmada siyasi partilerin referandum sürecinde yapmış oldukları siyasal iletişim faaliyetlerinin basında nasıl yer aldığını tespit etmek amaçlanmıştır. Bu kapsamda Hürriyet, Sabah, Sözcü ve Posta gazetelerinin 15 Nisan 2017, 16 Nisan 2017 ve 17 Nisan 2017 tarihlerinde birinci sayfalarında referandumla ilgili yapmış oldukları haberler Van Dijk'in söylem analizi yöntemi çerçevesinde incelenerek analiz edilmiştir. Söz konusu tarihler belirlenirken 15 Nisan 2017 tarihinin referandum seçiminden önceki gün olması, 16 Nisan 2017 tarihinin referandum seçiminin olduğu gün olması ve 17 Nisan 2017 tarihinin ise referandum seçim gününden sonraki gün olması temel alınmıștır.

\section{Siyasal Iletişim ve Medya}

İnsanların merak ettiği ve takip etmek istediği haber kategorilerinden biri siyasal gelişmelerdir. Siyasal gelişmelerle ilgili her türlü bilgiyi insanlara ulaştırmada en 
etkili araç ise medyadır. Teknolojinin gelişimiyle birlikte bilgiye ulaşmanın hızlı ve kolay olması medyanın önemini arttırmıştır. Bu durum siyasi aktörler açısından özellikle genel seçimler, yerel seçimler ve referandum gibi seçim dönemlerinde medyayı daha da önemli hale getirmektedir.

Siyasal iletişim, siyasal süreçlerle iletişim süreçleri arasındaki ilişkileri ele alan araştırmalardan oluşan disiplinler arası bir akademik alan olarak tanımlanmaktadır (Mutlu, 2012, 275). Çobanoğlu (2007, 46-47), siyasal iletişimin fonksiyonlarını haber, bilgi ve kültürün topluma iletilmesini sağlamak, siyasal katılımın artmasına katkıda bulunmak, yönlendirme veya yalana açık propagandalara karşı önlem almak, gündem yaratmak ve kamuoyu beklentilerini saptamak olarak belirlemektedir (Aktaran: Zeybek, 2016, 29-30). Siyasal iletişime yönelik çeşitli tanımlamalar yapılmasıyla birlikte kavramın iletişimden bağımsız olarak değerlendirilmesi doğru değildir. Siyasal iletişimi, sadece seçim dönemleriyle sınırlı tutmamak gerekir. Siyasal aktörlerin gerek seçim dönemlerinde ve gerekse diğer zamanlarda mesajlarını doğru bir şekilde anlatabilmeleri için öncelikle hedef kitleyle iletişime geçmeleri gerekmektedir.

Siyasal iletişimin üç temel unsurlarından biri kaynaktır. Siyasal iletişimde kaynak siyasal örgütlerden, aktörlerden oluşmaktadır. Söz konusu kaynaklar, siyasal mesajları medya aracılığıyla hedef kitleye gönderilmesini sağlamaktadır. İkinci temel unsur olan alıcı kitle, hedef kitle, siyasal mesajın gönderildiği taraf, halk, vatandaş, kamuoyudur. Siyasal iletişimin üçüncü temel unsuru ise siyasal içerikli mesajların halka ulaştırılmasını sağlayan kitle iletişim araçlarıdır (Aziz, 2015, 66). Yüz yüze iletişim gerçekleştirilerek siyasal iletişim sürecinden bahsedilebilir ancak daha çok hedef kitleye ulaşabilmek adına kitle iletişim araçları daha etkili ve önemlidir.

Demokrasi, medyanın siyasal sistem için birtakım görevlerini yerine getirmesini istemektedir. Gurevitch ve Blumler $(2014,194)$ bunlardan bazılarını şöyle sıralamıştır;

- Toplumsal ve siyasal çevrenin gözetiminin yapılarak halkı etkileyebilecek olumlu veya olumsuz gelişmelerle ilgi haberin verilmesi: Medyanın gerek ulusal gerekse uluslararası toplumu ilgilendiren ve etkileyen konularda olduğu gibi siyasal gelişmelerle ilgi de kamuoyunu bilgilendirmesi gerekmektedir.

- Siyasetçilerin, diğer baskı ve çıkar gruplarının görüşlerini aktarmalarını sağlamak adına platform görevi görme: Medyanın, yaşanan gelişmelerle ilgili birinci el kaynaklar olarak görülen ve haberin güvenirliğini artırmada da önemli rol oynayan kişilerin ilgili konu üzerindeki görüşlerini bildirecek ortamı oluşturmaları gerekmektedir.

- Çeșitli görüşlere sahip olanlar arasında, iktidarı ellerinde bulunduranlar (şimdi ve gelecekte) ile kitleler arasındaki diyalogu sağlama: Medyanın en önemli işlevlerinden biri de yöneten ve yönetilenler arasındaki köprüyü sağlayabilmektir. Medyanın bunu başarabilmesi için de iktidarda olanlara kitlelerin yaşamış oldukları sıkıntıları ve istekleri ulaştırması gerekmektedir.

- Siyasal süreçlerde halkı sadece izlemek ve konu hakkında konuşmalarını sağlamaktan ziyade söz konusu süreçleri öğrenmeleri, tercih yapmaları ve katılmaları yönünde teşvik etmek: Örneğin referandum seçimlerinde siyasal aktörlerin seçim kampanyalarında yapmış oldukları faaliyetlerle ilgili haberlerin yanında referandumun ne olduğu nasıl gerçekleşeceği anlatılmalıdır. 
Harrop ve Miller (1987, 221), parti ve seçmenler arasındaki bağlılığın zayıflaması, kitle iletişim araçlarının yeni konuları kapsaması ve insanların politikaları tartışması nedeniyle kitle iletişim araçlarının öneminin arttığını söylemektedir (Aktaran: Kalender, 2005, 121). Kitle iletişim araçlarının özellikle seçim sürecinde partilerin faaliyetlerini halka bildirmede önemli rolü bulunmakta ve seçmenlerin tercihleri üzerinde birtakım etkileri bulunmaktadır. Siyasi partiler, seçmenler ile ilişkilerini kuvvetlendirmek adına hem faaliyetlerini hem de gerekli açıklamalarını kitle iletişim araçlarıyla halka ulaştırmaktadırlar.

Medyanın toplum üzerindeki etkileri üzerinde duran önemli kuramlardan biri gündem belirleme kuramıdır. Büyüyen ve her geçen gün gelişen teknoloji sayesinde kitle iletişim araçlarının gündem belirleme noktasında önemli etkileri vardır.

"Gündem kuramının ana varsayımına göre, kitle iletişim araçları halka "ne düşüneceklerini söylemede" çoğu kez başarılı olmayabilir, fakat izleyicilerine "ne hakkında düşüneceklerini" anlatmada çok başarılıdır" (Tekinalp ve Uzun, 2013, 125). Gündem oluşturmayı Burton $(2008,221)$, haber medyasının materyali oluşturmak için belirli konuları düzenli olarak seçip hangi konuların izleyicinin esas ilgilendiği konu olması gerektiğine karar vermedeki süreç olarak ifade etmektedir. Yüksel'e $(2010,204)$ göre gündemi belirlemek, toplumsal sorunlara nasıl çözümler bulunacağı, bu sorunların çözümüne nereden başlanacağına karar verilmesi ve önceliklerin ne olduğunun belirlenmesi noktasında büyük önem arz etmektedir. Medyanın bu anlamda yaşanan olaylara yönelik hazırladığı öncelik sıralaması ile toplumun yanında siyasal aktörlere de hazır bir gündem sunmaktadır. Dolayısıyla hem kamuoyu hem de siyaset adamları bu gündemden etkilenmektedir. Gündem belirleme sadece halkın değil aynı zaman da siyasilerin de ne hakkında düşünecekleri noktasında etkilidir. Medya gerek seçim gerekse sonraki süreçlerde halkın istek, sorun, görüş ve önerileri hakkında gündem oluşturarak siyasilerin öncelikli olarak düşünecekleri konuyu belirleyebilir. Yaşanan sorunların gündeme getirilmesi ve çözüme ulaştırılması noktasında siyasilerin harekete geçirilmesi medyanın önemini ve etkisini arttırmaktadır.

Toplum üzerindeki etkileri açısından bakıldığında medya, önemsiz olarak değerlendirilen sıradan bir olayı gündeme getirerek önemli hale getirebilirken, önemli olarak görülebilecek bir olayı ise gündeme taşımayarak önemsiz hale getirebilir. Bir olay her ne kadar toplumu ilgilendirecek boyutta önemli olsa dahi medya tarafından yansıtılmadığı sürece kamuoyu oluşturma noktasında yeterli etki gücüne sahip olamaz. Kısaca kitle iletişim araçları istedikleri haberleri önemseyip büyütürken yine kendi istedikleri haberleri de küçültüp önemsizleştirmektedir. Kitle iletişim araçlarının bu yaklaşımı, kamuoyunun yönlendirilmesinde ve etkilenmesinde kullanılan bir yöntemdir (Özsoy, 2009, 40). Medya bir yandan insanların hangi konu üzerinde düşüneceğini belirleyip oluşturduğu gündemle dikkatleri bir yöne çekebilirken diğer yandan ülkede yaşanan daha önemli bir mevzuyu gündeme getirmeyerek önemsizleştirebilir.

\section{Haberde Söylem ve İdeoloji}

Söylem ve ideolojiye yönelik birçok tanımlamalar yapılmıştır. Ilgın $(2003,285)$ söylemin bildirişimdeki dil kullanımı, ideolojiyi ise düşünce ve inanç düzeni olarak tanımlanması durumunda söylemin içinde ideolojiyi barındırdı̆̆ını ve ideolojinin söylem oluşumundaki çerçeve olarak görülebilindiğini söylemektedir. 
Mutlu (2012, 280) söyleme yönelik dilbilimde cümlelerin üstünde dilin örgütlü bir biçimde kullanımı tanımını getirerek bu tanımın içinde farklı eğilimlerin de varsayılabileceğini ifade etmiştir. Mutlu ayrıca söylemi, ortak sayıltılarla bir araya getirilmiş ve bütünleşikleștirilmiş bir dil-kullanım alanı olarak açıklamıştır. Louis Althusser'in ideoloji kavramına değinen Güngör (2001, 221), Althusser'e göre ideolojinin maddi ve sınıfsal nitelikte, toplumsal ve siyasal roller üstlenmiş zihinsel bir tasarım olduğunu ve temel ișlevinin ise mevcut toplumsal formasyonu sürdürmek olduğunu belirtmiștir.

Karaduman ve Batu $(2011,363)$ haber söyleminde birçok unsurun etkili olduğuna ilişkin şu ifadelere yer vermişlerdir:

"Haber metinleri de içerik açısından birer söylemdir. Haberin söyleminin oluşmasında
haber kaynağı, haberin üretildiği kurumun ve toplumun ekonomi politiği, haber
profesyonelleri ve editoryal süreç, belirleyici bir rol oynamaktadır. Haber ve buna bağlı
olarak söylem, belirli bir üretim sürecinin sonunda oluşmaktadır. Bunun sonucunda
üretim sürecini kontrol edenlerin de parçası olduğu egemen ideoloji üretilmektedir.
Bu ideolojik unsurlar haber metininin düzenleniși ile oluşurlar. Çünkü haber metinleri
içerisinde belli egemen düşünceler, yaklaşımlar, anlatılar öne çıkarılır. Bunun sonucunda
belli dünya görüşlerini taşıyan ideolojik ve kapalı bir metin ortaya çıkar"

Devran (2010, 123), gazetecilerin ideolojisinin haber metinlerinin söylem yapısını etkilediğini söylemiştir. Muhabir, haberini oluştururken habere konu olan kişilere yönelik olumsuz ya da olumlu görüşünü ve ideolojisini yansıtabilmektedir. Van Dijk $(1998,33)$, ideolojik kare olarak nitelendirdiği ilkelerde, muhabirin kendi ideolojisini habere nasıl yerleştirdiği durumunu açıklamıştır. Söz konusu bu ilkeler şunlardır;

- Kendi iyi ve olumlu niteliklerinin ve eylemlerinin vurgulanması. Bu ilkeye göre muhabirler destekledikleri kişi veya kurumların yaptıkları olumlu faaliyetleri haber metinlerinde öne çıkarmaktadır.

- Ötekinin kötü ve olumsuz nitelik ve eylemlerine dikkat çekilmesi. Bu ilkede ise muhabirlerin haberlerini oluştururken karşıt oldukları kişi veya kurumların olumsuz eylemlerine dikkat çektikleri belirtilmektedir.

- Kendi kötü ve olumsuz eylem ve niteliklerinin göz ardı edilmesi fazla üzerinde durulmaması. Muhabir karşıt olduğu kişi veya kurumun olumsuz eylemlerini haber metinlerinde vurgularken desteklediği aktörlerin olumsuz bir eylemde bulunması halinde bu durumun üzerinde çok fazla durmamayı tercih etmektedir.

- Ötekinin olumlu ve başarılı eylemlerine önem verilmemesi ve gereğinden daha az dile getirilmesi. Bu ilke, muhabirlerin haber metinlerinde karşıt aktörlerin başarılı faaliyetlerini göz ardı ettiğini söylemektedir (Aktaran: Devran, 2010, 123-124).

\section{Nisan 2017 Referandum Oylaması}

Halkın referandumda yapacakları oylamada tercihlerini etkileyebilme açısından sürdürülen yoğun siyasal iletișim faaliyetlerini kamuoyuna ulaștırmada medyanın önemli bir etkisi vardır. Medyanın halkı bilgilendirme misyonunu ülkenin başka konularla ilgili gündeminde yaşanan gelişmelerinde olduğu gibi referandum sürecinde de sürdürmesi gerekmektedir. Siyasi partilerin referandumda yürüttükleri çalışmaların medyada haber olarak yer alması halkın aydınlatılması noktasında önem arz ederken medyanın kamuoyunu bilgilendirme işlevini de tarafsızlık ilkesi bağlamında gerçekleştirme hususunda gereken hassasiyeti göstermelidir. 
TDK referandumu, halkın türlü siyasi ve toplumsal sorunlar karşısında olumlu veya olumsuz görüşünü belirlemek için başvurulan oylama olarak açıklamaktadır (tdk.gov.tr, 2017). Referandum genellikle anayasa değişikliği, yasaların kabulü ya da ülkeyi ilgilendiren çok önemli meselelerde halkın iradesini belirlemek amacıyla yapılan oylama olarak da tanımlanmaktadır (turkcebilgi.com, 2017). Halkın özgür iradesi, ülkenin önemli konularında referandum aracılığıyla kararların alınmasına ortak edilmesiyle doğrudan doğruya siyasal yaşama yansımaktadır. Böylelikle referandum yarı doğrudan demokrasisinin güzel bir örneğini teşkil etmektedir (Göker ve Doğan, 2011, 47).

Seçim kampanyalarının yanında referandumu da kapsayan kampanyalar siyasal kampanyalar olarak değerlendirilmektedir. Kamuoyunu doğrudan ilgilendiren hususlarda o ülkenin gerek siyasal ve gerekse yönetsel yapısına bağlı olarak parlamentosu, hükümeti, bölgesel (eyalet) ve yerel yönetimleri ülke sorunları ile ilgili olarak büyük önem atfeden konularda doğrudan karar vermeyip halkın kararına başvurmaları durumunda referandum gerçekleşir. Yönetenler tarafindan halkın görüşüne başvurulduğu ve dolayısıyla alınan kararlara halkın ortak edildiği konular genellikle şu şekildedir (Aziz, 2007, 106);

- Savaş ilanı durumu,

- Yeni bir anayasanın onaylanması veya var olan bir anayasanın önemli bir maddesinin değiştirilmesi,

- Halkın kendi geleceğini belirlemesi amacıyla yasal, yönetsel ve yargısal bir konu üzerinde önemli bir değişikliğin yapılması (idamın kaldırılması vb.).

Türkiye'nin referandum tarihine baktığımızda bugüne kadar toplamda 7 kez referandumun gerçekleştiğini görmekteyiz. Türkiye'de yapılan referandumların yapıldı̆̆ı tarihler ve sonuçları şu şekildedir (gelgez.net, 2017);

9 Temmuz 1961: Türkiye'nin ilk referandumu, 9 Temmuz 1961 tarihinde gerçekleştirildi. 27 Mayıs 1960 askeri darbesinin ardından hazırlanan 1961 Anayasası için referandumda yüzde 61.7 'evet', yüzde 38.3 'hayır' oyu kullanıldı. Katılım oranının \% 81 olduğu referandumda 1961 Anayasası kabul edildi.

7 Kasım 1982: Türkiye'nin ikinci referandumu 7 Kasım 1987 tarihinde 1982 Anayasası için yapıldı. 12 Eylül 1980 askeri darbesi sonrası yapılan referandumda yüzde 8.63 'hayır' oyuna karşılık yüzde 91.37 'evet' oyla yeni anayasa kabul edildi.

6 Eylül 1987: 1982 Anayasasında parti liderlerine ve yöneticilerine yönelik siyasi yasaklar konulmuştu. Söz konusu siyasal yasakların kalkıp kalkmaması hususunda 6 Eylül 1987'de yapılan referandum sonuçlarına göre seçmenler, yüzde 50.16 'evet', yüzde 49.84 'hayır' oyu kullandı. Yapılan referandum sonucuna göre siyasi yasaklı olan parti liderleri seçimlere katılma hakkına sahip oldular.

25 Eylül 1988: Türkiye'nin dördüncü referandumu 25 Eylül 1988'de gerçekleştirildi. Referandum, 1982 Anayasası'nın 127. maddesindeki yerel seçimlerin 1 yıl öne alınıp alınmaması konusuyla ilgiliydi. Referandum sonucunda yüzde 65 'hayır', yüzde 35 'evet' yönünde oy kullanılarak yerel seçimlerin 1 yıl erkene alınmasına dair anayasa değişikliği reddedildi. 
21 Ekim 2007: Türkiye’nin beşinci referandumu cumhurbaşkanının halk tarafından seçilmesine ilişkindi. Yapılan referandum sonucunda sandıktan yüzde 68.95 'evet', yüzde \%31.05 'hayır' oyu çıkarak anayasa değişikliği kabul edildi.

12 Eylül 2010: Türkiye'nin altıncı referandumu 2010 tarihinde gerçekleştirildi. Anayasanın 26 maddesine ilişkin referandum sonucunda yüzde 57.88 'evet', yüzde 42.12 'hayır' oyu kullanıldı.

16 Nisan 2017: Türkiye'de seçmenler 16 Nisan 2017 tarihinde yapılan yedinci referandum için sandık başına gitti. Seçmenler tarafından referandumda oylanan anayasa değişikliği paketi, yürürlükteki parlamenter sistemin kaldırılarak başkanlık sisteminin getirilmesine ve birtakım anayasa değişikliğine ilişkindi. 18 maddelik anayasa değişikliğini kapsayan referandum için yapılan oylamada yüzde 51.41 'evet', yüzde 48.59 'hayır' sonucu çıtı. Böylelikle yapılan referandumda anayasa değişikliği kabul edildi.

\section{Amaç ve Önem}

Seçim dönemlerinde partilerin yaptıkları siyasal iletişim faaliyetleri seçmenin oy kararını önemli derecede etkilemektedir. Basın, seçim sürecinde söz konusu faaliyetleri daha geniş kitlelere duyurma noktasında önemli bir araç olarak görülmektedir. Türkiye'de yapılan genel seçimler, yerel seçimler ve referanduma yönelik birtakım araştırmalar bulunmaktadır. Göker ve Doğan'ın (2011) yaptığı çalışmada Türkiye'deki 2010 referandum sürecinin basında nasıl yer aldı̆̆ incelenmiştir. Çalışma sonucunda gazetelerin siyasal gündemi yansıtma konusunda birbirinden farklı bir yayın politikası içerisinde olduğu belirlenmiştir. Advan (2016) 'AK Parti Döneminde Bir Seçim Analizi: 7 Haziran-1 Kasım 2015 Genel Seçimleri'nin Gazete Manşetlerindeki Sunumu' adlı çalışmasında 7 Haziran 2015 genel seçimleri ve 1 Kasım 2015 erken genel seçim sonuçlarının gazete manşetlerine yansımalarını incelemiştir. Bu çalışma ise, Türkiye'de 16 Nisan 2017 tarihinde yapılan yedinci referandumu ele alması ve referandum sürecinde siyasal iletişim faaliyetlerinin basına yansıma biçimlerini ortaya koyması açısından önemli görülmüştür. Seçim dönemlerinde basının haberlerini nesnellik bağlamında ideolojik yanlılıktan uzak tarafsız bir şekilde sunması gerekmektedir. Çalışmada basının referandum sürecinde siyasal partilerin yapmış oldukları siyasal iletişim faaliyetlerini nasıl yansıttığını ortaya koymak amaçlanmıştır. Yapılan çalışmada ayrıca aşağıda belirtilen soruların cevaplanması amaçlanmıştır;

- Referanduma ilişkin haberlerde olumlu ya da olumsuz yargılar kullanılmış mıdır?

- Tematik yapı çerçevesinde başlık, haber girişi, spot ve fotoğraf haber metninin ana fikrini vermiş midir?

- Haber başlıkları, ideolojik anlamlarla yüklü müdür?

- Haber metinlerinde kullanılan cümle yapısı nedir? (etgen\&edilgen).

- Haberde hangi retorik unsurlar kullanılmıștır? (fotoğraf, sayısal veriler, puntolar, inandırıcı bilgiler ve görgü tanıklarının ifadeleri gibi)

- Gazetelerin referandumla ilgili yapmış oldukları haberlerde editöryal yanlılığı gösteren ifadeler kullanılmış mıdır? 


\section{Yöntem}

$\mathrm{Bu}$ çalışmada ulusal gazetelerdeki haberler Van Dijk'in söylem analizi yöntemi ile makro ve mikro yapıları çerçevesinde incelenmiştir. Hollandalı bir dilbilimci olan Dijk'in ilk çalışmaları edebiyata dilbilimsel yaklaşımlar üzerine olsa da daha sonralarda metin dilbilim ve söylem çözümlemesi alanlarına yönelerek birtakım çalışmalar yapmıştır (İnceoğlu ve Çokmak: 2016, 33). Van Dijk'in haber söylem çözümlemesinde belirttiği makro yapı çözümlemesi çerçevesinde metnin teması, tematik yapısı ve konusu incelenirken mikro yapı da ise metnin sesleri, sözcükleri, cümle yapıları ve anlamları analiz edilmektedir (Devran, 2010, 64). Söylem çözümlemesi modelinde makro yapı, tematik ve şematik olmak üzere ikiye ayrılmaktadır. Tematik yapı başlıkları, haber girişleri ve fotoğrafları, şematik yapı ise ana olayın sunumu, sonuçları, ardalan bilgisi, bağlam bilgisi, haber kaynakları ve olay taraflarının olaya ilişkin getirdikleri yorumları kapsamaktadır. Mikro yapı, sentaktik çözümleme, bölgesel uyum, sözcük seçimleri ve haber retoriğinden oluşmaktadır. Sentaktik çözümlemede cümle yapılarının aktif ya da pasif, basit ya da karmaşık olması öne çıkar. Bölgesel uyumda nedensel, işlevsel ve referansal ilişkiler belirlenirken haber retoriğinde ise fotoğraflar, inandırıcı bilgiler ve görgü tanıklarının ifadeleri yer almaktadır (Özer, 2011, 85).

Çalışmanın evrenini Türkiye'deki ulusal basın oluşturmaktadır. Örneklem ise gazetelerin tirajları göz önünde bulundurularak en üst sıralamalarda olan Hürriyet, Sabah, Sözcü ve Posta olmak üzere toplamda 4 gazete olarak belirlenmiștir. Van Dijk'in söylem analizi çerçevesinde gazetelerin birinci sayfalarındaki manşet haberleri incelenmiştir. Çalışma kapsamında gazetelerin referandum seçiminden önceki 1 gün, referandum seçiminin olduğu gün ve referandum seçim gününden sonraki 1 gün yayınlamış oldukları haberler ele alınmıştır. Dolayısıyla bu çalışmada Hürriyet, Sabah, Sözcü ve Posta gazetelerinin 15 Nisan 2017, 16 Nisan 2017 ve 17 Nisan 2017 tarihlerinde birinci sayfalarında referandumla ilgili yapmış oldukları toplamda 12 haber Van Dijk'in söylem analizi yöntemi çerçevesinde incelenerek analiz edilmiştir. Bu araştırmada Aslı Advan'ın (2016) '7 Haziran- 1 Kasım 2015 Genel Seçimleri'nin Gazete Manşetlerindeki Sunumu’ adlı çalışmasında geliştirilen tablolardan yararlanılmıștır.

\section{Bulgular ve Yorumları}

\section{Makro Yapısal Analiz}

Tablo 1: Tablo Adı?

\begin{tabular}{|c|c|c|c|c|c|c|}
\hline & \multicolumn{6}{|c|}{15 Nisan 2017} \\
\hline & $\begin{array}{l}\text { Haberin } \\
\text { Konumu }\end{array}$ & Üst Başlık & Ana Başlık & Alt Başık & Spot & Metnin Girişi \\
\hline 离 & Manşet & - & SON MESAJLAR & $\begin{array}{l}\text {-iSPATLASINLAR } \\
\text { ISTiFA EDERIM } \\
\text { EYALET } \\
\text { MADDESI YOK } \\
\text {-EYALETi } 50 \text { KEZ } \\
\text { SÖYLEDILER } \\
\text { BU KADAR } \\
\text { YETKI NEDEN } \\
\text {-AKP'DEN 7 BILIM } \\
\text { INSANINDAN } \\
\text { SES YOK }\end{array}$ & $\begin{array}{l}\text { Cumhurbaşkanlığı } \\
\text { sistemi öngören } \\
\text { Anayasa değişikliği } \\
\text { için yapılacak tarihi } \\
\text { referanduma bir } \\
\text { gün kala liderler } \\
\text { 'kararsız' seçmeni } \\
\text { etkilemek için son } \\
\text { çağrılarını yapıyorlar. }\end{array}$ & $\begin{array}{l}\text {-Başbakan Yıldırım, } \\
\text { Bahçeli'yle başlayan } \\
\text { 'eyalet sistemi' } \\
\text { tartışmasına şu } \\
\text { sözlerle... } \\
\text {-CHP Lideri eyalet } \\
\text { sistemi tartısması için } \\
\text { konuştu:"Eyalet olacak } \\
\text { mı olmayacak mı? ... } \\
\text {-Cumhurbaşkanı'nı } \\
\text { eyalet açıklaması için } \\
\text { "Fazlasıly yeterli" } \\
\text { yorumu yapan Bahçeli, } \\
\text { "18 madde... }\end{array}$ \\
\hline
\end{tabular}




\begin{tabular}{|c|c|c|c|c|c|c|}
\hline 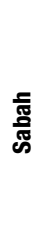 & Manşet & $\begin{array}{l}\text { CUMHUR } \\
\text { BAŞKANI } \\
\text { ERDOĞAN } \\
\text { SABAH'A YAZDI } \\
16 \text { NISAN İLERI } \\
\text { DEMOKRASI } \\
\text { YOLUNDA YENI } \\
\text { BAŞLANGIÇ }\end{array}$ & $\begin{array}{l}\text { ÜNITER YAPIYI } \\
\text { İLELEBET } \\
\text { SÜRDÜRECEĞiz }\end{array}$ & $\begin{array}{l}\text {-Bïi } \\
\text { BÖLEMEYECEKLER } \\
\text {-'EVET’LER AÇIK } \\
\text { ARA ÖNDE’ }\end{array}$ & $\begin{array}{l}\text { Cumhurbaşkanı } \\
\text { Erdoğan, Konya'da } \\
\text { noktayı koydu: } \\
\text { Eyalet, federasyon } \\
\text { gibi dedikodulara } \\
\text { kanmayın. Hiçbiri } \\
\text { gündemimizde yok. }\end{array}$ & $\begin{array}{l}\text { TÜRKIYE'NiN üniter } \\
\text { yapısının en büyük } \\
\text { savunucusu, şahsım } \\
\text { başta olmak üzere } \\
\text { daima biz olduk. }\end{array}$ \\
\hline $\begin{array}{l}\text { : } \\
\text { : } \\
\text { : }\end{array}$ & Manşet & $\begin{array}{l}\text { Bahçeli'nin } \\
\text { gece yarısı çıkışı } \\
\text { siyaseti karıştırdı }\end{array}$ & $\begin{array}{l}\text { EYALET } \\
\text { BOMBASI! }\end{array}$ & $\begin{array}{l}\text { EVET CEPHESI } \\
\text { GERGIN }\end{array}$ & $\begin{array}{l}\text { Sandıktan "Evet" } \\
\text { çıkması halinde } \\
\text { eyalet sisteminin } \\
\text { geleceğine iliş̧kin } \\
\text { iddialar yeni bir } \\
\text { tartışma başlattı... } \\
\text { "Evet" cephesinde } \\
\text { dün kriz vardı!.. }\end{array}$ & $\begin{array}{l}\text { MHP lideri Bahçeli, } \\
\text { eyalet tartışmalarına } \\
\text { sert çıktı... }\end{array}$ \\
\hline $\begin{array}{l}\text { జ } \\
\text { फू }\end{array}$ & Manşet & - & $\begin{array}{l}\text { EYALET } \\
\text { ATIŞMASI }\end{array}$ & $\begin{array}{l}\text {-TARTIŞMA } \\
\text { BU SÖZLERLE } \\
\text { BAŞLAMIŞTI } \\
\text {-SEN BENIM } \\
\text { DEDIĞIME BAK } \\
\text {-iSPAT EDIN } \\
\text { ISTIFA EDEYIM } \\
\text {-: SIZ YENI Mi } \\
\text { KEŞFETTINIZ? } \\
\text {-EYALETi } \\
\text { SAVUNUYOR } \\
\text {-KAÇMAYA } \\
\text { HAZIRLANIYOR }\end{array}$ & $\begin{array}{l}\text { MHP lideri Devlet } \\
\text { Bahçeli'nin } \\
\text { "Cumhurbaşkanı } \\
\text { Danışmanı'nın eyalet } \\
\text { sistemini savunması } \\
\text { MHP oylarını sabote } \\
\text { etmektedir. Ben } \\
\text { olsam görevden } \\
\text { alırım" demesi } \\
\text { referanduma saatler } \\
\text { kala siyasette bomba } \\
\text { etkisi yarattı. İşte } \\
\text { liderlerin açıklamaları }\end{array}$ & $\begin{array}{l}\text {-MHP lideri Bahçeli } \\
\text { önceki gün şöyle } \\
\text { dedi: “... } \\
\text {-“"Danışmanımın bir } \\
\text { açılılaması olmuş. } \\
\text {-“Eğer bu anayasanın } \\
\text { herhangi bir yerinde...” } \\
\text {-“Türkiye parçalanacak } \\
\text { mı parçalanmayacak } \\
\text { mı? ... } \\
\text {-“Cumhurbaşkanı } \\
\text { Erdoğan'ın } \\
\text { 2013’te canlı... } \\
\text {-“Bahçeli } 16 \text { Nisan } \\
\text { akşamı 'Hayır’ } \\
\text { çıacağını gördü. }\end{array}$ \\
\hline
\end{tabular}

15 Nisan 2017 tarihinde Hürriyet gazetesi makro yapısal analizi çerçevesinde tematik açıdan incelendiğinde referandum konulu haberin manşetten verildiği görülmüştür. Haberin üst başlığı bulunmazken ana başlık 'son mesajlar' olarak verilmiștir. Alt başlık ise AK Parti, CHP ve MHP liderlerinin ifadelerinden oluşmuştur. Haberin spotunda ise cumhurbaşkanlığı sistemi öngören anayasa değişikliği için yapılacak referanduma bir gün kala liderlerin 'kararsız' seçmeni etkilemek için son çağrılarını yaptıklarına vurgu yapılmıştır. Haberde genel olarak üzerinde durulan ve öne çıkarılan nokta referandum öncesi parti liderlerinin eyalet sistemi üzerindeki tartışmalarıdır. $\mathrm{Bu}$ anlamda haberde ana başlık, alt başlıklar, metnin girişi ve fotoğraflar arasında uyum söz konusudur. Haber şematik olarak incelendiğinde ana olayın haber girişinde sunulduğu görülmüştür. Haberde parti liderlerinin yorumlarına yer verilmesi haberin etkisini ve önemini arttırması açısından önemlidir.

Hürriyet gazetesinin haberi mikro yapısal analizde sentaktik açıdan incelendiğinde cümlelerde çoğunlukla etken yapılı fiillerin kullanıldığı belirlenmiştir. Mikro yapısal analizde haberin etkisini arttıran önemli unsurlardan biri retoriktir. Haberde genel olarak parti liderlerinin referandumla ilgili kendi ifadelerine yer verilmiştir. Yani haberde sıkça doğrudan alıntı yapıldığı görülmüştür. Referandum öncesi liderlerin konuşmalarına yer verildiği haberin ana başlığı da 'SON MESAJLAR' şeklinde beyaz iri puntolarla yazılmıştır. Haberde ifadelerine yer verilen AK Parti, CHP ve MHP liderlerinin fotoğrafları alt başlıklar kısmında bulunmaktadır.

Sabah gazetesi referandum haberini makro yapısal analizde tematik olarak üst başlık, ana başlık, spot ve metnin girişini manşetten sunmuştur. Haberde 'ÜNITER YAPIYI ILLELEET SÜRDÜRECEĞİ' ana başlı̆̆l, spot ve fotoğraf haber metninin konusunu yansıtır niteliktedir. Haberin spot kısmında Cumhurbaşkanı Recep Tayyip Erdoğan'ın eyalet, federasyon gibi dedikodulara kanılmaması gerektiği yönündeki ifadelerine yer verilmiştir. Başlıklar ve metin girişi incelendiğinde genel olarak üniter yapının sürdürüleceği üzerinde durulmuştur. Şematik açıdan ise ana olayın metin girişinde sunulduğu görülmüştür. Haberde başlıklar, spot ve metin içeriğinden anlaşılacağı 
üzere üniter yapının sürdürüleceği ardalan bilgisi olarak verilmiștir.

Sabah gazetesinin haberi mikro yapı bakımından incelendiğinde genel olarak başlıklar ve metin girişinde etken yapılı fiillerin kullanıldığı görülmüştür. Etken yapıdaki cümlelerde Cumhurbaşkanı Erdoğan'ın ifadeleri yorumlanmadan doğrudan alıntı șekliyle yansıtılmıştır. Haberin spotunda bulunan 'Cumhurbaşkanı Erdoğan, Konya'da noktayı koydu' metnindeki noktayı koymak ibaresi editöryal bir yanlılıkla sunulmuştur. Yine metin içerisinde mitinge katılımın 'coşkulu' bir şekilde gerçekleștiğinin ifade edilmesi sözcük seçimleriyle taraflı bir sunumun olduğunu göstermektedir. Haberde ana başlık sarı iri puntolarla yazılırken 'BIZI BÖLEMEYECEKLER', “EVET'LER AÇIK ARA ÖNDE' alt başlıkları ise kırmızı puntolarla yazılmıştır. Haberlerde kullanılan fotoğraflar retorik açıdan haberin etkisini ve gücünü arttırmasından dolayı oldukça önemlidir. Sabah gazetesinin referandum haberinde Cumhurbaşkanı Erdoğan'ın Konya mitingindeki sağ elini kalbine koyarak ve hafif gülümseyerek halkı selamladığı bir fotoğrafa ve halkın bulunduğu miting alanından bir fotoğrafa yer verdiği belirlenmiștir.

Sözcü gazetesi makro yapısal analiz bakımından incelendiğinde referandum haberini manşetten verdiği üst başlıkta ise 'Bahçeli'nin gece yarısı çıkışı siyaseti karıştırdı' ifadesini kullandığı belirlenmiştir. Haberin spot kısmı ise referandum sonucunda 'evet' çıkması halinde eyalet sisteminin geleceğine dair iddiaların yeni bir tartışma başlattığına yöneliktir. Şematik açıdan haberde eyalet sistemindeki tartışmalar ardalan bilgi olarak verilmiştir. Haberin ana başlık, alt başlıklar, metnin girişi ve fotoğrafların birbirleriyle uyumlu olduğu belirlenmiştir.

Sözcü gazetesi mikro yapısal analiz bakımından incelendiğinde sentaktik açıdan haber başlıklarında ve giriş metninde etken yapılı fiiller kullanmıştır. 'Evet cephesi gergin', 'Evet' cephesinde dün kriz vardı!...' gibi başlıklar ve spotta kullanılan ifadeler haberde yanlılık olduğunun göstergesidir. Haber retorik açıdan değerlendirildiğinde ise 'EYALET BOMBASI!' ana başlığının beyaz iri puntolarla oluşturulması, korku, şaşkınlık ve heyecan verici gibi duyguları ifade eden ünlem (!) işaretinin kullanılması anlamlı görülmüştür. 'EVET CEPHESI GERGİN' alt başlı̆̆ı ise kırmızı puntolarla verilmiştir. Spotta yer alan "sandıktan "Evet" çıkması..." ifadesindeki sandık sözcüğüyle seçmenler kastedilerek mecaz-ı mürsel yapılmıştır. Bir diğer mecaz-ı mürsel örneği de 'EVET CEPHESİ GERGINN' ifadesidir. Haberde 'evet' cephesi olarak kastedilen kişiler, Cumhurbaşkanı Erdoğan, Başbakan Yıldırım ve MHP lideri Bahçeli'dir. Retoriği güçlendiren önemli unsurlardan biri olan fotoğraf Sözcü gazetesinde de kullanılmıștır. Gazetenin haberinde Cumhurbaşkanı Erdoğan, Başbakan Yıldırım ve MHP lideri Bahçeli'nin bir arada oldukları bir fotoğrafın üzerine sohbet balonları eklenmiştir ve her bir sohbet balonunun içerisine konuyla ilgili ifadeler yerleştirilmiştir.

Posta gazetesi referandum haberini makro yapısal analizde tematik açıdan ana başlık, spot ve metnin girişine yer vererek manşetten sunmuştur. Gazetede haberin üst başlığına yer verilmemiştir. 'EYALET ATIŞMASI' ana başlığı metin içeriğinde de yer alan eyalet sistemi üzerindeki tartışmaları yansıtır niteliktedir. Haberin spotunda MHP Lideri Bahçeli'nin "Cumhurbaşkanı Danıșmanı'nın eyalet sistemini savunması MHP oylarını sabote etmektedir. Ben olsam görevden alırım” sözlerinin tartışmaya yol açması üzerinde durulmaktadır. Haberde başlıklar, spot, metin giriși ve fotoğraf uyumlu görülmüştür. Haberde MHP Lideri Bahçeli'nin tartışmalara yol açan sözleri hatırlatılarak ardalan bilgi verilmiştir. 
Posta gazetesinin haberi mikro yapısal analizde sentaktik açıdan incelendiğinde genel olarak etken yapılı fiillerin kullanıldı̆̆ı görülmüştür. Ayrıca haberde tarafların ifadelerine doğrudan alıntı yöntemiyle tırnak içerisinde yer verilmiştir. Haberin retoriğini etkileyen unsurlardan bazıları başlıkların renkleri, puntoları ve puntoların boyutudur. Posta gazetesinin referandum haberinde ana başlık sarı iri puntolardan oluşmuştur. Habere konu olan taraflara ait toplamda altı fotoğraf kullanılmıştır.

\section{Makro Yapısal Analiz}

Tablo 2: Tablo Adı?

\begin{tabular}{|c|c|c|c|c|c|c|}
\hline & \multicolumn{6}{|c|}{16 Nisan 2017} \\
\hline & $\begin{array}{l}\text { Haberin } \\
\text { Konumu }\end{array}$ & Üst Başlık & Ana Başlık & Alt Başık & Spot & Metnin Girişi \\
\hline 预 & Sürmanşet & - & $\begin{array}{l}\text { SÖZ } \\
\text { SANDIKTA }\end{array}$ & - & $\begin{array}{l}18 \text { maddelik Anayasa } \\
\text { değişikliği için bugün } \\
\text { yurtiçinde } 55 \text { milyon } \\
319 \text { bin } 222 \text { seçmen, } \\
167 \text { bin } 140 \text { sandıkta } \\
\text { oy kullanacak. }\end{array}$ & $\begin{array}{l}\text { Oy vermeye giderken yanınızda } \\
\text { seçmen bilgi kâğıdınızı ve } \\
\text { TC kimlik numaranızı yazan } \\
\text { kimlik bulundurun. }\end{array}$ \\
\hline 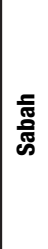 & Manşet & $\begin{array}{l}\text { TEK MILLET, } \\
\text { TEK BAYRAK, } \\
\text { TEK VATAN, } \\
\text { TEK DEVLET } \\
\text { içiN }\end{array}$ & $\begin{array}{l}\text { HAYDI } \\
\text { SANDIĞA }\end{array}$ & $\begin{array}{l}-167 \text { BIN SANDIK } \\
\text { KURULDU } \\
\text {-YEDINCI } \\
\text { REFERANDUM }\end{array}$ & $\begin{array}{l}55 \text { milyon seçmen } \\
\text { Cumhurbaşkanliğı } \\
\text { Hükümet Sistemi'ni } \\
\text { öngören anayasa } \\
\text { değişikliği } \\
\text { referandumu için } \\
\text { bugün sandık } \\
\text { başına gidiyor }\end{array}$ & YENI Türkiye için tarihi gün. \\
\hline $\begin{array}{l}\text { : } \\
\text { : }\end{array}$ & Sürmanşet & - & $\begin{array}{l}\text { ÜLKEN içiN } \\
\text { SANDIĞA GiT }\end{array}$ & $\begin{array}{l}\text { Cumhuriyet } \\
\text { tarihinin en kritik } \\
\text { anayasa oylaması } \\
\text { bugün... } \\
\text { HAYDi TÜRKIYE } \\
\text { SANDIK BAŞINA }\end{array}$ & - & 60 günlük miting maratonu bitti.. \\
\hline 咹 & Manşet & - & $\begin{array}{l}\text { YARIN } \\
\text { ISSTE BU } \\
\text { TÜRKIYE'YE } \\
\text { UYANMAK } \\
\text { iSTIYORUZ }\end{array}$ & $\begin{array}{l}-18 \text { MADDELIK } \\
\text { PAKET } \\
\text { OYLANACAK } \\
\text {-SONUCU } \\
\text { KATILIM ORANI } \\
\text { BELIRLEYECEK }\end{array}$ & $\begin{array}{l}\text { BUGÜN SANDIĞA } \\
\text { GiTMEYENIN ŞIKAYET } \\
\text { ETMEYE HAKKI YOK! } \\
\text { OY VER }\end{array}$ & $\begin{array}{l}\text {-Türkiye, tarihinin en } \\
\text { kritik oylaması için bugün } \\
\text { sandık başına gidiyor. } \\
\text {-Güvenlik için } 380 \text { bin } 223 \\
\text { asker ve polis önlem alacak. }\end{array}$ \\
\hline
\end{tabular}

Bu tabloda 16 Nisan 2017'de çalışma kapsamında incelenen gazetelerde yer alan referandum haberleri incelenmiştir. Hürriyet gazetesi referandum haberini makro yapısal analiz tematik yapı çerçevesinde sürmanșetten vermiștir. Haberin üst başlığına ve alt başlığına yer verilmezken ana başlık 'SÖZ SANDIKTA' olarak belirtilmiştir. Haberde şematik yapı açısından seçmenlerin oy vermeye giderken ve oy kullanırken nelere dikkat etmeleri gerektiğine yönelik ardalan bilgi verilmiştir. Bu bakımdan haberin başlığı, spotu, metin girişi ve fotoğrafı uyumludur.

Hürriyet gazetesindeki referandum haberinde sentaktik çözümleme açısından etken yapılı cümleler kullanılmıştır. Ana başlık iri siyah puntolarla yazılmıştır ve 'SÖZ SANDIKTA' ana başlığında 'sandık' sözcüğüyle seçmen kastedilerek mecaza dayalı sanatlardan biri olan mecaz-ı mürsel (ad aktarması) yapılmıştır. Retorik açıdan bakıldığında ise referandum için kaç kişinin oy kullanacağına dair sayısal veriler belirtilmiş ve böylece haberin inandırıcılığı ve ikna edici etkisi arttırılmıştır. Haberde kullanılan fotoğrafta ise oy zarfını sandığa atan bir seçmen eli görülmektedir.

Sabah gazetesi referandum haberini makro yapısal analizde tematik açıdan ana başlık, alt başlık, üst başlık, spot ve metnin girişine yer vererek manşetten sunmuştur. Haberin spotu seçmenlerin Cumhurbaşkanlığı Hükümet Sistemi'ni öngören anayasa değişikliği referandumu için sandığa gidip oy kullanmaları üzerinedir. 
Haberde 'TEK MILLET, TEK BAYRAK, TEK VATAN, TEK DEVLET IÇIN' üst başlığının devamı olarak koyulan 'HAYDI SANDIĞA' ana başlığının yanı sıra Cumhurbaşkanı Recep Tayyip Erdoğan'ın fotoğrafının verilmesi gazetenin seçmenlere 'evet' oyunu kullanmaları yönünde mesaj verdiği dolayısıyla habere ideolojik anlam yüklediği belirlenmiștir. Haberde șematik yapı olarak Türkiye'nin referandum tarihine ilișkin ardalan bilgi verilmiştir.

Sabah gazetesi mikro yapısal analiz çerçevesinde incelendiğinde sentaktik açıdan haber başlıklarında ve giriş metninde etken yapılı fiillerin yanında '167 BIN SANDIK $K U R U L D U^{\prime}$ alt başlığında olduğu gibi edilgen fiiller de kullanmıştır. Retorik açıdan değerlendirildiğinde haberde ana başlık beyaz iri puntolarla yazılmıştır. Haberde ayrıca referandumda kaç sandık kurulduğu ve kaç seçmenin oy kullanacağına ilişkin verilere değinilerek haberin etkisi arttırılmıştır. Haberde Cumhurbaşkanı Erdoğan'ın mitinglerde halka seslendiği fotoğraf kullanılmıştır ayrıca fotoğrafın arka planında ise Türk bayrağına fon olarak yer verilmiștir.

Sözcü gazetesinin referandum haberi makroyapısal analizdetematikyapı bakımından değerlendirildiğinde üst başlık ve spota yer verilmediği ana başlık ve alt başlığın ise sürmanşetten yansıtıldığı belirlenmiştir. Haberin ana başlığı ÜLKEN İÇIN SANDIĞA GİT' olarak belirlenmiştir. Haberin başlığı, metin girişi ve kullanılan fotoğraf uyumlu görülmüştür. Haberde genel anlamda referanduma yönelik seçmenlerin sandık başına gidip oylarını kullanmaları yönündeki metinler yer almaktadır.

Sözcü gazetesindeki referandum haberinde, mikro yapısal analizde sentaktik çözümleme açısından incelendiğinde etken yapılı cümlelerin kullanıldığı görülmüștür. "Tek bir oy bile çok değerli", "sandığa git, Türkiye’nin geleciğine sahip çık", "Cumhuriyet tarihinin en kritik anayasa oylaması bugün..." ifadelerini kullanan gazete, örtük olarak editöryal yanlılık içerisinde olmuştur. Sözcük seçimleri mikro yapısal analizde önemli unsurlardan biridir. 'HAYDI TÜRKIYYE SANDIK BAŞINA' alt başlığında 'Türkiye' sözcüğü ile Türk halkı kastedilerek mecaz-ı mürsel yapılmıștır. Haberde ayrıca konuyla ilgili bağlantılı olarak sandığa oy zarfını atan bir seçmen eli görülmektedir. Haberde 'ÜLKEN IÇIIN SANDIĞA GIT' ana başlığı beyaz ve çok iri puntolarla sürmanșetten verilerek haber değerinin ve içeriğinin önemi arttırılmak istenmiştir.

Posta gazetesinin referandum haberi makro yapısal analizde tematik açıdan incelendiğinde üst başlığa yer verilmediği ana başlığın, alt başlığın ve spotun ise manșetten sunulduğu belirlenmiştir. '18 MADDELIK PAKET OYLANACAK' ve 'SONUCU KATILIM ORANI BELIRLEYECEK' alt başlıkları yazılarak metin içinde oy işlemleri üzerine genel bilgiler verilmiştir. Metin girişinde ise Türkiye’nin tarihindeki en kritik oylaması için sandık başına gittiğine vurgu yapılarak seçimin önemi belirtilmiștir. 'BUGÜN SANDIĞA GITTMEYENIN ŞIKAYYET ETMEYE HAKKI YOK! OY VER' spotuyla da seçmenlerin mutlaka sandığa gidip oy kullanmaları gerektiği aksi halde seçim sonuçlarından şikayet etme haklarının olmadığı vurgulanmıştır.

Posta gazetesinin haberi mikro yapısal analizde sentaktik açıdan incelendiğinde çoğunlukla etken yapılı fiillerin yanında edilgen yapılı fiillerin de kullanıldığı belirlenmiștir. Haberde 'YARIN ISSTE BU TÜRKIYY'YE UYANMAK ISTIYORUZ' ana başlığı iri siyah puntolarla oluşturulmuştur. Söz konusu başlığın altına 'evet' ve 'hayır' yazılı kıyafetlerini giyinmiş olan iki vatandaştan birinin elini diğerinin omzuna attığı fotoğraf koyulmuştur. Posta gazetesi bu fotoğrafla birlik beraberlik 
ve 'sonuç ne olursa olsun omuz omuzayız' mesajlarını vermiştir. Oylamanın hangi saatler arasında yapılacağına, kaç kişinin oy kullanacağına ve kaç partilinin sandık başında görev yapacağına ilişkin sayısal veriler kullanılarak haberin retorik açıdan etkisi arttırılmıştır.

Makro Yapısal Analiz

Tablo 3: Tablo Adı?

\begin{tabular}{|c|c|c|c|c|c|c|}
\hline & 17 Nisan & & & & & \\
\hline & $\begin{array}{l}\text { Haberin } \\
\text { Konumu }\end{array}$ & Üst Başlık & Ana Başlık & Alt Başılık & Spot & Metnin Girişi \\
\hline 莡 & Manşet & 94 YIL SONRA & $\begin{array}{l}\text { YENI } \\
\text { SISTEM }\end{array}$ & $\begin{array}{l}-1.3 \text { MiLYON } \\
\text { OY FARKLA } \\
\text {-BÜYÜKŞEHIRLER:17 } \\
\text { HAYIR } 13 \text { EVET }\end{array}$ & $\begin{array}{l}1923 \text { 'ten bu } \\
\text { yana uygulanan } \\
\text { parlamenter sistemden } \\
\text { cumhurbaşkanlığı hükümet } \\
\text { sistemine geçişi öngören } \\
18 \text { maddelik anayasa } \\
\text { değişikliği kabul edildi. }\end{array}$ & $\begin{array}{l}\text {-Cumhuriyet tarihinin 7'nci } \\
\text { anayasa referandumu } \\
\text { yönetim sistemi... } \\
\text {-Referandumda en yüksek } \\
\text { 'evet' oyu yüzde } 81.67 \\
\text { ile Bayburt, en yüksek... }\end{array}$ \\
\hline 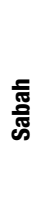 & Manşet & - & $\begin{array}{l}\text { HALK } \\
\text { IHTILALi }\end{array}$ & $\begin{array}{l}\text {-HALK KENDI } \\
\text { SiSTEMINI SEÇTi } \\
\text {-MiLLET ERDOĞAN'A } \\
\text { SAHIP ÇIKTI }\end{array}$ & $\begin{array}{l}\text { Referandumda tarihi bir } \\
\text { zafere imza atan Türk } \\
\text { milleti, Cumhurbaşkanı } \\
\text { Erdoğan'ın öncüsü } \\
\text { olduğu Cumhurbaşkanlığı } \\
\text { Hükümet Sistemine 'evet' } \\
\text { dedi değişim başladı }\end{array}$ & $\begin{array}{l}\text {-TÜRK milleti } 15 \\
\text { Temmuz'da hain darbe } \\
\text { girişimine karşı başlattığı } \\
\text { kahramanca direnişi } \\
\text { sandıkta taçlandırdı. }\end{array}$ \\
\hline 芯 & Manşet & - & $\begin{array}{l}\text { VICDANINIZ } \\
\text { RAHAT MI? }\end{array}$ & $\begin{array}{l}\text {-GÖZ GÖRE GÖRE } \\
\text { OY SAHTEKARLIĞII } \\
\text { YAPTILAR } \\
\text {-“OH OH” DEYIP } \\
\text { EVETLERI } \\
\text { MÜHÜRLEDi } \\
\text {-MUHTAR OY } \\
\text { TEFTiŞi YAPTI } \\
\text {-SANDIK BAŞKANI, } \\
\text { SANDIK AÇLDIKTAN } \\
\text { SONRA MÜHÜRSÜZ } \\
\text { OYLARI MÜHÜRLEDi }\end{array}$ & $\begin{array}{l}\text { Yüksek Seçim Kurulu, } \\
\text { mühürsüz oyları son } \\
\text { anda geçerli sayınca } \\
\text { referandumun seyri } \\
\text { değişti...2 } 2.5 \text { milyon } \\
\text { oyun şaibeli olduğu } \\
\text { iddia edildi. Toplumun } \\
\text { yarısı böyle sordu. }\end{array}$ & $\begin{array}{l}\text {-Bu görüntüler dün } \\
\text { Şanllurfa'da çekildi. } \\
\text {-Muş'ta AKP'li bir } \\
\text { muhtarın seçmenlerle oy } \\
\text { kabinine girip 'Evet'... } \\
\text {-Ankara Sincan'da oy } \\
\text { verme işlemi bittikten } \\
\text { sonra, sandıktan YSK... }\end{array}$ \\
\hline 焉 & Manşet & - & $\begin{array}{l}\text { ZAFER } \\
\text { DE YOK } \\
\text { HEZIMET DE }\end{array}$ & $\begin{array}{l}\text {-KATILIM ORANI } \\
\text { YÜZDE } 86 \\
\text {-7 BÜYÜK } \\
\text { ŞEHIRDEN 'HAYIR' } \\
\text {-HARRAN VE } \\
\text { OVACIK'TA REKOR }\end{array}$ & $\begin{array}{l}97 \text { yıllık parlamenter sistemi } \\
\text { bitirip 'Cumhurbaşkanlığı } \\
\text { Hükümet Sistemi'ni getiren } \\
\text { anayasa değişikliği } 2.7 \\
\text { puan farkla (1 milyon } 252 \text {. } \\
\text { bin oyla) kabul edildi. } \\
\text { Yeni sistem } 3 \text { Kasım } \\
2019 \text { 'daki milletvekili ve } \\
\text { cumhurbaşkanlığı seçimi } \\
\text { sonrası devreye girecek. }\end{array}$ & $\begin{array}{l}\text {-Seçime katılım oranı } \\
\text { yüzde } 86 \text { oldu. } \\
\text {-7 büyük şehirde (İstanbul, } \\
\text { Ankara, İzmir, Adana, } \\
\text { Antalya, Mersin ve... } \\
\text {-'Evet'in en yüksek } \\
\text { çıktığı iller; Bayburt, } \\
\text { Rize, Gümüşhane. }\end{array}$ \\
\hline
\end{tabular}

Hürriyet gazetesinin referandum haberi makro yapısal analizin tematik yapısı bakımından değerlendirildiğinde sürmanşetten verilmiștir. Haberde 'YENI SISTEM' ana başlık olarak '1.3 MILLYON OY FARKLA', 'BÜYÜKŞEHIRLER:17 HAYIR 13 EVET' alt başlık olarak yer almıştır. Haberin spotunda ise 1923'ten bu yana uygulanan parlamenter sistemden cumhurbaşkanlığı hükümet sistemine geçişi öngören 18 maddelik anayasa değişikliğinin kabul edilmesi vurgulanmıştır. Haberde şematik yapı açısından 'evet' cephesindeki AK Parti ve MHP'nin 1 Kasım 2015 seçimlerinde aldıkları oyların yüzdelerine ilişkin bilgiler verilerek önceki seçimde oyların daha yüksek olduğu bu seçimde ise oy kaybı yaşadıkları ardalan bilgi olarak belirtilmiştir. Bir diğer ardalan bilgi ise 1 Kasım 2015 seçimlerinde 697 bin geçersiz olan oy sayısının bu referandum seçiminde 847 bin 537'e yükselişinin verilmesidir.

Hürriyet gazetesindeki referandum haberi, mikro yapısal analizde sentaktik çözümleme açısından incelendiğinde etken yapılı ve edilgen yapılı fiillerin 
kullanıldığı görülmüștür. Haberin ana başlığı iri beyaz puntolarla oluşturulurken üst başlık ise sarı iri puntolarla kırmızı fon üzerinde belirtilerek retorik açıdan haber dikkat çekici kılınmıştır. Haberde referandum seçim sonuçlarının illere göre dağılımı haritayla gösterilmiştir. Oy sonuçlarına ilişkin sayısal veriler kullanılarak haberin etkisi arttırılmıștır.

Sabah gazetesi 17 Nisan 2017 tarihinde referanduma ilişkin haberinde makro yapısal analizde tematik olarak üst başlığa yer vermezken ana başlığı, alt başlı̆̆ı ve spotu manșetten sunmuştur. Haberin spotu 'TÜRK milleti 15 Temmuz'da hain darbe girişimine karşı başlattığı kahramanca direnişi sandıkta taçlandırdı' olarak sunulmuştur. Gazetenin 'HALK IHTILALI' ana başlığı ve 'MILLLET ERDOĞAN'A SAHIPP ÇIKTI ' alt başlığı ideolojik bir yanlılığın olduğunu göstermektedir. Haberin başlık, spot ve fotoğrafı uyumlu olarak görülmüştür. Haberde şematik yapı açısından Türk halkının 15 Temmuz'daki darbe girişimine karşı direnişi ardalan bilgi olarak verilmiştir.

Sabah gazetesi referandum haberinde, mikro yapısal analizde sentaktik çözümleme açısından değerlendirildiğinde çoğunlukla etken yapılı fiilleri kullandığı görülmüştür. Haberin 'tarihi bir zafere imza atan', 'evet'in zaferi,' 'halk demokrasi dersi verdi', 'güçlü liderliğe 'evet' diyen halk" gibi ifadelerinde nesnellikten uzak yanlı bir söylem söz konusudur. 'Referandum sürecinde her türlü faşizmi sergileyen Batı' ifadesinde de söz sanatlarından biri olan mecaz-1 mürsel kullanılmıştır. Gazetenin 'HALK IHTILALI' ana başlığı beyaz iri puntolarla haberde yer almıștır. Haberde kullanılan fotoğrafta Cumhurbaşkanı Erdoğan ve eşi Emine Erdoğan halkı selamlamaktadır.

Sözcü gazetesinin referandum haberi makro yapısal analizde tematik açıdan incelendiğinde üst başlığa yer verilmediği ana başlığın, alt başlığın ve spotun ise manşetten sunulduğu görülmüştür. Haberde başlıklar, spot ve kullanılan fotoğrafların uyumlu olduğu belirlenmiştir. Haberin genel itibariyle Yüksek Seçim Kurulunun, mühürsüz oyları son anda geçerli sayması üzerinedir. Haberin başlıklarında yer alan 'VICDANINIZ RAHAT MI?', 'GÖZ GÖRE GÖRE OY SAHTEKARLIĞI YAPTILAR', 'OH OH DEYIP EVETLERI MÜHÜRLEDI' ifadeler haberin nesnellikten uzak ideolojik anlamlarla yüklü olduğunu göstermektedir. Haberde şematik olarak Yüksek Seçim Kurulu'nun seçim gününde mühürsüz oyları son anda geçerli sayması durumu ardalan bilgi olarak verilmiştir.

Sözcü gazetesi mikro yapı bakımından incelendiğinde referandum haberinde genel olarak başlıklar, spot ve metin girişindeki cümleler etken ve edilgen yapıdadır. Haberde yer alan "makineli tüfek gibi 'evet' oylarını bastı" ve "seri şekilde mühür bastı" șeklindeki ifadelerin nesnellikten uzak bir yaklaşım olduğu belirlenmiștir. Haberin ana başlığı iri beyaz puntolarla yazılırken 'GÖZ GÖRE GÖREOY SAHTEKARLIĞI YAPTILAR' alt başlığı ise kırmızı iri puntolarla yansıtılarak okuyucuların dikkati çekilmiştir. 'OH OH DEYIP EVETLERI MÜHÜRLEDI', 'MUHTAR OY TEFTISSI YAPTI', ve 'SANDIK BAŞKANI, SANDIK AÇILDIKTAN SONRA MÜHÜRSÜZ OYLARI MÜHÜRLEDI' alt başlıkları kısmında haberin içeriğini güçlendirme, ikna ve inandırma gücünü arttırma amacıyla 3 ayrı fotoğraf kullanılmıştır.

Posta gazetesi ise referandum haberini makro yapısal analiz tematik yapı çerçevesinde üst başlık olmadan sürmanşetten yansitmıştır. 'ZAFER DE YOK HEZIMET DE' ana başlığıyla gazete haberini nesnel bir yaklaşımla oluşturmaya çalışmıştır. Haberin genelinde ise seçim sonuçlarına ilişkin bilgiler verilmektedir. 
Haberde şematik yapı açısından AK Parti ve MHP'nin 1 Kasım 2015'teki genel seçimdeki oyunun yüzde 61 iken referandum seçiminde yüzde 51 olması yani bir oy düşüşünün yaşanması ardalan bilgi olarak verilmiștir.

Posta gazetesi haberde mikro yapı bakımından incelendiğinde genel olarak başlıklarda, spotta ve metin girişinde etken yapılı fiiller kullanmıştır. Gazetede Yüksek Seçim Kurulu'nun, mühürsüz oyları son anda geçerli sayması gerekçe gösterilerek referandumun seyrinin değiştirildiği belirtilmiştir. Bu noktada haberde bölgesel uyum açısından nedensel ilişki kurulmuştur. Haberde seçmenlerin referandum sonucunu kutlamalarını gösteren bir fotoğraf kullanılmıştır. Seçim sonuçlarına dair sayısal verilere yer verilerek haberin retorik açıdan etkisi arttırılmıştır. 'ZAFER DE YOK HEZIMET DE' ana başlığı haberde sarı iri puntolarla yazılmıştır.

\section{Sonuç}

Siyasal iletişim kapsamında siyasal aktörlerin faaliyetlerinin ve mesajlarının halka ulaştırılmasını sağlayan en önemli unsurlardan biri basındır. Özellikle genel seçimler, yerel seçimler ve referandum gibi seçim dönemlerinde basın en önemli araç olarak görülmektedir. Araştırmada gazetelerin referandum sürecinde partilerin siyasal iletişim faaliyetlerini nasıl yansıttığını ortaya koymak amaçlanmıştır. Bu amaç doğrultusunda Hürriyet, Sabah, Sözcü ve Posta gazetelerinin 15 Nisan 2017, 16 Nisan 2017 ve 17 Nisan 2017 tarihlerinde referandumla ilgili birinci sayfalarından vermiş oldukları toplamda 12 manşet haber incelenmiştir. Haberler Van Dijk'in söylem analizi yöntemi çerçevesinde makro yapısal analizde tematik ve şematik açıdan, mikro yapısal analizde sentaktik, bölgesel uyum, sözcük seçimleri ve retorik açısından incelenerek değerlendirmeler yapılmıştır.

Sabah gazetesi 'EVET'LER AÇIK ARA ÖNDE', 'MILLLET ERDOĞAN'A SAHIP ÇIKTI', ve 'HALK KENDİ SISTEMINİ SEÇTİ' başlıklarıyla referandumu destekleyici ifadeler kullanarak seçim sonucunun 'evet' çıkmasını editöryal yanlılıkla sunmuştur. Sözcü gazetesi ise 'EVET CEPHESİ GERGIN', 'VICDANINIZ RAHAT MI?' ve 'GÖZ GÖRE GÖRE OY SAHTEKARLIĞI YAPTILAR' başlıklarıyla referandumda 'evet' çıkmasına yönelik tepkili ifadelere yer vererek haberlerini editöryal yanlılıkla yansıtmıştır. Araştırmada 15 Nisan 2017 ve 16 Nisan 2017 tarihlerinde Sabah ve Sözcü gazetelerinin referanduma yönelik haberlerinde örtük olarak yanlılığın olduğu tespit edilmiştir. Söz konusu iki gazetenin ideolojik anlamlarla yüklü ifadelere en fazla seçim sonuçlarının gazetelere yansıdığı gün olan 17 Nisan 2017 tarihinde yer verdiği tespit edilmiștir. Haberlerde zaman zaman referanduma yönelik olumlu ve olumsuz yargılar kullanılmıştır. Haberin etkisini arttıran retorik unsurlara yer verilmiştir. Bazı haber başlıklarının ideolojik anlamlarla yüklü olduğu görülmüştür. Haberlerde tematik yapı çerçevesinde çoğunlukla başlık, haber giriși, spot ve fotoğraf haber metninin ana fikrini vermiştir.

Sonuç olarak incelenen gazetelerin bazı haberlerinde ideolojik anlamlarla yüklü ifadelere yer verdikleri ve nesnellikten uzak editöryal bir yanlılıkla haberlerini sunarak tarafsız kalamadıkları belirlenmiştir. Basının seçim dönemlerinde partilerin siyasal iletişim faaliyetlerini kamuoyuna ulaştırıp bilgilendirme işlevini yerini getirirken ideolojik yanlılıktan uzak nesnel bir tutum içerisinde olmalıdır. 


\section{Kaynakça}

Advan, A. (2016). AK Parti Döneminde Bir Seçim Analizi: 7 Haziran- 1 Kasım 2015 Genel Seçimleri'nin Gazete Manşetlerindeki Sunumu, S. Aslan ve Y. Demirhan (Ed.). Türk Siyasal Hayatında Ak Parti Dönemi (s.323-355). Bursa: Ekin Yayınevi.

Aziz, A. (2007). Siyasal İletişim. Ankara: Nobel Akademik Yayıncılık.

Aziz, A. (2015). Siyasal İletişim. Ankara: Nobel Akademik Yayıncılık.

Burton, G. (2008). Görünenden Fazlası, (N. Dinç, Çev.). İstanbul: Alan Yayıncılık.

Devran, Y. (2010). Haber Söylem İdeoloji. İstanbul: Başlık Yayın Grubu.

Göker, G. ve Doğan, A. (2011). 2010 Referandumunda Türk Basınının Siyasal Gündemi: Hürriyet, Haber Türk, Zaman ve Yeni Şafak Örneğiyle [Elektronik Sürüm]. Gümüşhane Üniversitesi İletişim Fakültesi Elektronik Dergisi, 1(2), 45-69.

Gurevitch, M ve Blumler G. J. (2014). Siyasal İletişim Sistemleri ve Demokratik Değerler, S. İrvan (Der.). Medya Kültür Siyaset (s. 193-212). Ankara: Pharmakon Yayınevi.

Güngör, S. (2001). Althusser'de İdeoloji Kavramı [Elektronik Sürüm]. Süleyman Demirel Üniversitesi İktisadi ve İdari Bilimler Fakültesi Dergisi, 6 (2), 221231.

Ilgın, L. (2003). Söylem ve İdeoloji, B. Çoban ve Z. Özarslan (Ed.). Söylem ve İdeolojiMitoloji, Din, İdeoloji (285-298). İstanbul: Su Yayınevi.

İnceoğlu, G. Y. ve Çokmak, A. N. (2016). Metin Çözümlemeleri. İstanbul: Ayrıntı Yayınları.

Kalender, A. (2005). Siyasal İletişim. Seçmenler ve İkna Stratejileri. Konya: Çizgi Kitabevi.

Karaduman, S ve Batu N.M. (2011). Televizyon Haberlerinde Terörizm Olgusunun TRT’nin Haber Söylemi Bağlamında Incelenmesi [Elektronik Sürüm]. Selçuk Üniversitesi Sosyal Bilimler Enstitüsü Dergisi, (25), 359-374.

Mutlu, E. (2012). İletişim Sözlüğü. Ankara: Sofos Yayınları.

Özer, Ö. (2011). Haber Söylem İdeoloji. Eleştirel Haber Çözümlemeleri. Konya: Literatürk Yayınları.

Özsoy, O. (2009). Seçim Kazandıran Siyasal İletişim. İstanbul. Pozitif Yayınları.

Tekinalp, Ş. ve Uzun, R. (2013). İletişim Araștırmaları ve Kuramları. İstanbul: Beta Basim.

Yüksel, E. (2010). Medya ve Habercilik. Konya: Çizgi Kitabevi.

Zeybek, B. (2016). Siyasal Reklam ve Retorik. İstanbul: Beta Basım.

gelgez.net. (2017). Erişim: 25 Haziran 2017, https://www.gelgez.net/turkiyedereferandum-kac-kez-yapildi-kac-kere-anayasa-degisti/

ucankus.com . (2017). Erişim: 10 Haziran 2017, http://www.ucankus.com/ detay/278761/iste-gazetelerin-nisan-ayi-tirajlari 
tdk.gov.tr.(2017). Erişim: 29 Haziran2017, http://tdk.gov.tr/index.php?option=com gts\&arama=gts\&guid=TDK.GTS.5954bc4ad045b4.34498694

turkcebilgi.com . (2017). Erişim: 25 Haziran 2017, https://www.turkcebilgi.com/ referandum 